\title{
Novel members of bacterial community during a short-term chilled storage of common carp (Cyprinus carpio)
}

\author{
Edit Kaszab $^{1}$ - Milán Farkas ${ }^{2} \cdot$ Júlia Radó $^{1} \cdot$ Adrienn Micsinai $^{5} \cdot$ Brigitta Nyírő-Fekete $^{5} \cdot$ István Szabó $^{3}$. \\ Balázs Kriszt ${ }^{1}$ - Béla Urbányi ${ }^{4}$ - Sándor Szoboszlay ${ }^{1}$
}

Received: 23 April 2021 / Accepted: 23 November 2021 / Published online: 7 December 2021

(c) The Author(s) 2021

\begin{abstract}
This work aimed to identify the key members of the bacterial community growing on common carp (Cyprinus carpio) fillets during chilled storage with next-generation sequencing (NGS) and cultivation-dependent methods. Carp fillets were stored for $96 \mathrm{~h}$ at $2{ }^{\circ} \mathrm{C}$ and $6{ }^{\circ} \mathrm{C}$ with and without a vacuum package, and an additional frozen-thawed storage experiment was set for 120 days. Community profiles of the initial and stored fish samples were determined by amplicon sequencing. Conventional microbial methods were used parallelly for the enumeration and cultivation of the dominant members of the microbial community. Cultivated bacteria were identified with 16S rRNA sequencing and the MALDI-TOF MS method. Based on our results, the vacuum package greatly affected the diversity and composition of the forming microbial community, while temperature influenced the cell counts and consequently the microbiological criteria for shelf-life of the examined raw fish product. Next-generation sequencing revealed novel members of the chilled flesh microbiota such as Vagococcus vulneris or Rouxiella chamberiensis in the vacuum-packed samples. With traditional cultivation, 161 bacterial strains were isolated and identified at the species level, but the identified bacteria overlapped with only $45 \%$ of the dominant operational taxonomic units (OTUs) revealed by NGS. Next-generation sequencing is a promising and highly reliable tool recommended to reach a higher resolution of the forming microbial community of stored fish products. Knowledge of the initial microbial community of the flesh enables further optimization and development of processing and storage technology.
\end{abstract}

Edit Kaszab and Milán Farkas contributed equally to this work.

Edit Kaszab

kaszab.edit@uni-mate.hu

1 Department of Environmental Safety, Institute of Aquaculture and Environmental Safety, Hungarian University of Agriculture and Life Sciences, 1 Páter Károly, 2100 Gödöllő, Hungary

2 Department of Molecular Ecology, Institute of Aquaculture and Environmental Safety, Hungarian University of Agriculture and Life Sciences, 1 Páter Károly, 2100 Gödöllő, Hungary

3 Department of Environmental Toxicology, Institute of Aquaculture and Environmental Safety, Hungarian University of Agriculture and Life Sciences, 1 Páter Károly, 2100 Gödöllő, Hungary

4 Department of Aquaculture, Institute of Aquaculture and Environmental Safety, Hungarian University of Agriculture and Life Sciences, 1 Páter Károly, 2100 Gödöllő, Hungary

5 WESSLING Hungary Ltd, 6 Anonymus, 1045 Budapest, Hungary

$\begin{array}{ll}\text { Abbreviations } & \\ \text { AP } & \text { Air-packed } \\ \text { CFU } & \text { Colony forming unit } \\ \text { FAP } & \text { Frozen-thawed aerobic package } \\ \text { FAV } & \text { Frozen-thawed vacuum package } \\ \text { LAB } & \text { Lactic acid bacteria } \\ \text { MALDI-TOF } & \begin{array}{l}\text { Matrix-assisted laser desorption ionization } \\ \text { time-of-flight }\end{array} \\ \text { MPN } & \text { Most probable number } \\ \text { MS } & \text { Mass spectrometry } \\ \text { NCBI-SRA } & \text { National Center for Biotechnology Infor- } \\ & \text { mation - Sequence Read Archive } \\ \text { NGS } & \text { Next-generation sequencing } \\ \text { OTU } & \text { Operational taxonomic unit } \\ \text { PBS } & \text { Phosphate buffered saline } \\ \text { PCR } & \text { Polymerase chain reaction } \\ \text { SSO } & \text { Specific spoilage organisms } \\ \text { TGY agar } & \text { Tryptone, glucose, yeast extract agar } \\ \text { TMA } & \text { Trimethylamine } \\ \text { T-RFLP } & \text { Terminal restriction fragment length } \\ & \text { polymorphism } \\ \text { VP } & \text { Vacuum-packed }\end{array}$




\section{Introduction}

Common carp is an extremely perishable food ( $\mathrm{Li}$ et al. 2017a); spoilage occurs rapidly leading to a limited shelflife for carp products (Gram and Huss 1996). Spoilage of carp products is due to unstable chemical composition and microbial growth (Sterniša et al. 2016). The growing microbial community is the most common cause of biochemical changes leading to spoilage of fish products and making them unacceptable for human consumption (Arashisar et al. 2004).

The initial microbial load and the first few days of storage have a significant effect on the microbiological quality (Odeyemi et al. 2020). The initial bacterial community of stored carp is mainly composed of psychrotrophic Gram-negative bacteria from the genera Pseudomonas, Moraxella, Acinetobacter, Shewanella, and Flavobacterium (Gram and Huss 1996). Depending on their spoilage potential, some of these organisms may contribute to the quality changes of fish (Beaz-Hidalgo et al. 2014). The fraction of the total initial microbiota with a role in spoilage is called the specific spoilage organisms (Parlapani et al. 2014). During storage, the microbial community of the stored carp dramatically changes due to the influence of several intrinsic or extrinsic factors. Therefore, in the critical phases, such as the first few days of storage, it is important to determine the key members of the microbial community down to the species level. To identify the species of bacteria from samples, traditional cultivation methods, often merged with 16S rRNA gene sequencing, have been utilized previously (Zhang et al. 2015; Wang et al. 2017). Based on these findings, a total of 13 different genera comprised the microbial communities of fresh common carp fillets with the dominance of Acinetobacter species. In airpacked (AP) samples, Pseudomonas became dominant on day 4, while in vacuum-packed (VP) samples, Aeromonas constituted the largest group on day 6. During storage of VP carp fillets, $\mathrm{H}_{2} \mathrm{~S}$ producing bacteria and especially lactic acid bacteria (LAB) counts increased slightly towards the end of the shelf life (Zhang et al. 2015).

High-resolution techniques such as next-generation sequencing (NGS) have been used recently in the microbial characterization of stored fish products. With the combination of a culture-based method and high-throughput sequencing, the predominance of Aeromonas and Lactococcus species was revealed in refrigerated common carp samples (Zhang et al. 2017a). In spoiled freeze-chilled muscle samples of common carp, Pseudomonas proved to be the dominant genus ( $\mathrm{Li}$ et al. 2018). However, the resolution of these research works reached the genus level only and did not identify the key species of the stored carp fillet. Similarly, culture-independent NGS methods of crucian carp (Carassius auratus) showed the predominance of Pseudomonas

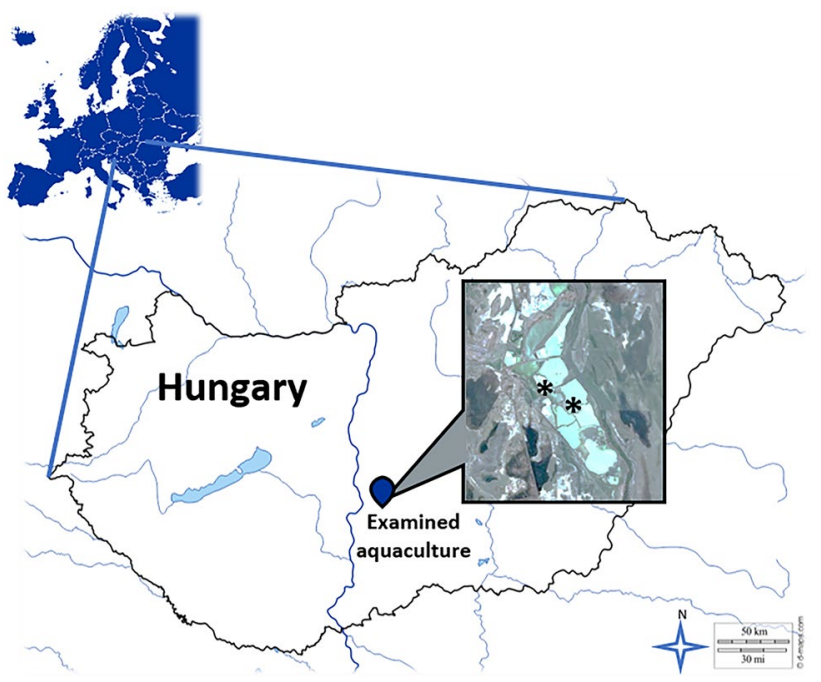

Fig. 1 Location of the sampling site of the chosen Hungarian aquaculture. Sampling points are marked with an asterisk (original maps: d-maps.com ${ }^{\circledR}$, Google Earth $^{\circledR}$ )

during partial freezing and chilled storage (Zhang et al. 2017b), while the microbial characterization of vacuumpacked crisp grass carp (Ctenopharyngodon idella) revealed the dominance of Aeromonas and Pseudomonas species (Pan et al. 2018). Based on an overview of the scientific literature, we could not find any next-generation sequencing result of stored common carp microbiome determination at a species level. Similarly, no NGS results represented the European production and processing conditions of common carp. Therefore, this work aimed to follow the microbial changes in carp fillet samples originating from a Hungarian aquaculture under different storage temperatures $\left(2^{\circ} \mathrm{C}, 6^{\circ} \mathrm{C}\right.$, frozen-thawed) and package (aerobic package, and vacuum package) conditions for $96 \mathrm{~h}$ with cultivation-dependent and cultivation-independent methods. The cultivation-dependent approach combined isolation techniques with partial $16 \mathrm{~S}$ rRNA sequencing and MALDI-TOF MS, while next-generation sequencing was the chosen cultivation-independent technique to identify the dominant bacterial taxa.

\section{Materials and methods}

\section{Sampling and packaging}

The sampling site was a shallow fishpond located in the sodic area of Central Hungary with a semi-intensive (low population density) aquaculture (Fig. 1). Waterbody and sediment were sampled in 2018 autumn at two points (marked with an asterisk) representing inflow water and the waterbody of the fishpond. The microbiological state 
of the waterbody was revealed by the pour plate technique (MSZ EN ISO 6222 2000). Water chemistry parameters were determined by Wessling Hungary Ltd. (Budapest, Hungary) with standardized analytical methods (MSZ EN ISO 9963-1 1998; MSZ EN ISO 10304-1 2009; MSZ EN ISO 17294-2 2005). Fifteen common carp (Cyprinus carpio) with average body mass $(2.5 \pm 0.5 \mathrm{~kg})$ were obtained from the fishpond in the same autumn period. Live carps were immediately transported to the fish processing facility under regular conditions (storage tank with water temperature around $15{ }^{\circ} \mathrm{C}$ ), where a standard processing procedure was used (stunning, slaughtering, cleaning, desliming, descaling, gutting, and sectioning into de-skinned fillets with $100 \pm 20 \mathrm{~g}$ average mass). Good hygiene practice and a high degree of cleaning were taken into consideration. During processing, all abiotic surfaces that came into contact with the carp flesh (scaling table, deskinning table, filleting table, packaging table, scale, package) were sampled and examined for the enumeration of microorganisms with standardized methods (MSZ EN ISO 4833-1 2014). Carp fillets were individually packaged in both AP and VP form and were stored for the expected time of microbial stabilization (96 h) at $2 \pm 1{ }^{\circ} \mathrm{C}$ and $6 \pm 1{ }^{\circ} \mathrm{C}$ in both package types for subsequent bacterial analysis. As frozen storage is a common method for preservation of fish products (Ježek and Buchtová 2010), a 120-day-long storage experiment was set at $-18 \pm 2{ }^{\circ} \mathrm{C}$ with both aerobic package (FAP) and vacuum package (FAV). All settings were performed in triplicates. The microbial community of initial samples, chilled and frozen-thawed AP, and VP samples were all characterized as follows.

\section{Cultivation-independent microbial characterization}

Illumina 16S rRNA amplicon sequencing was used to precisely assess the bacterial community composition of the chosen samples. DNA was extracted with the DNeasy tissue kit (Qiagen, Germany) from 10 to $20 \mathrm{mg}$ tissue samples following the instructions of the manufacturer. For paired-end 16S rRNA amplicon sequencing, the variable V3 and V4 regions of the 16S rRNA gene were amplified by using primers with Illumina adapter overhanging oligonucleotides (Klindworth et al. 2013). Each polymerase chain reaction (PCR) contained $12.5 \mathrm{ng}$ of DNA, $0.2 \mu \mathrm{mol} / \mathrm{L}$ of each Illumina $16 \mathrm{~S}$ primers, and $12.5 \mu \mathrm{L}$ of 2X KAPA HiFi HotStart Ready Mix (KAPA Biosystems, London, UK) supplemented with molecular grade water to $25 \mu \mathrm{L}$ final volume. The PCR temperature profile was the following: initial denaturation for $5 \mathrm{~min}$ at $95{ }^{\circ} \mathrm{C}$ and 25 cycles of amplification $\left(30 \mathrm{~s}\right.$ at $95{ }^{\circ} \mathrm{C}, 30 \mathrm{~s}$ at $55^{\circ} \mathrm{C}$, $30 \mathrm{~s}$ at $72{ }^{\circ} \mathrm{C}$ ). The last step was a final extension for 5 min at $72{ }^{\circ} \mathrm{C}$. All amplifications were carried out in a ProFlex PCR System (Applied Biosystems by Life Technologies, USA). Amplicons were analysed by agarose gel electrophoresis. Paired-end fragment reads were generated on an Illumina MiSeq sequencer using MiSeq Reagent Kit v3 (600-cycle). Read numbers ranged between 68,526 and 94,833 . Primary data analysis (base-calling) was carried out with Bcl2fastq^ software (v2.17.1.14, Illumina). Reads were quality- and length-trimmed in CLC Genomics Workbench Tool 9.5.1 using an error probability of 0.05 (Q13) and a minimum length of 50 nucleotides as a threshold. Trimmed sequences were processed using mothur $\mathrm{v}$ 1.41.1 (Schloss et al. 2009) as recommended by the MiSeq SOP page (http://www.mothur.org/wiki/MiSeq_SOP) (Kozich et al. 2013). Sequences were assorted based on the alignment using the SILVA 132 SSURef NR99 database (Quast et al. 2013). Chimera detection was performed with mothur's uchime command (Edgar et al. 2011), and 'split.abund' command was also used to remove singleton reads according to Kunin et al. (2010). The standard 97\% similarity threshold was used to determine operational taxonomic units (OTUs) as suggested by Tindall et al. (2010) for prokaryotic species delineation. For specieslevel identification, pair-end sequences were screened for a minimum length of $400 \mathrm{bp}$ ('screen.seqs' command), which enables species prediction (Franzén et al. 2015). Raw sequence reads were deposited in the National Center for Biotechnology Information - Sequence Read Archive (NCBI-SRA) under BioProject ID PRJNA613591. The most abundant OTUs were also identified by using the EzBioCloud 16S rRNA gene database (Yoon et al. 2017). Shannon-Weaver diversity indexes were calculated based on $16 \mathrm{~S}$ amplicon sequencing data by the mothur software.

\section{Isolation and enumeration of bacterial community}

With a robust cultivation approach using the pour plate technique with three different cultivation media, our aim was to compare the effectiveness of commonly used cultivation and 16S rRNA-based identification with the NGS method and to validate NGS to species-level identification of storage microorganisms. Fillets were sampled and examined by standardized microbial methods for enumeration and isolation of microorganisms (ISO 6887-2 2003; ISO 6887-3 2017). A 25-g batch from each sample was homogenized with phosphate-buffered saline (PBS) in a 1:10 ratio. A series of tenfold dilution was prepared in PBS, and all levels of dilutions were plated with a modified tryptone glucose yeast extract (TGY) agar (tryptone, $10 \mathrm{~g}$, glucose $1 \mathrm{~g}$, yeast extract, $10 \mathrm{~g}$, bacteriological agar, $18 \mathrm{~g}$, distilled water, $1 \mathrm{~L}$ ), a medium recommended for environmental samples and food products, for the determination of colony forming units (cfus) and for the isolation of dominant cultivable bacteria. Incubation parameters were $28 \pm 1{ }^{\circ} \mathrm{C}$, $96 \mathrm{~h}$. For selective isolation, additional media were used parallelly. Acinetobacter spp. were cultivated on Acinetobacter CHROMagar $^{\mathrm{TM}}$ (Paris, France), Aeromonads were grown on 
Aeromonas Medium (LabM, Neogen, UK). After the incubation period, TGY plates and the applied selective/differential media were visually checked, and the colony forming units (cfu) were determined. Colonies with visible differences in morphology were subcultured for further investigations.

\section{Bacterial identification}

Bacterial strains were priorly identified by matrix-assisted laser desorption ionization time-of-flight (MALDI-TOF) mass spectrometry (MS) method using a Bruker Biotyper system (Bruker Daltonics, Leipzig, Germany). For MALDITOF MS identification, bacterial samples were prepared according to the instructions of Bruker Daltonics. Biological material $(0.1-0.2 \mathrm{mg})$ of the examined culture was smeared as a thin film directly onto the spot on a MALDI target plate and was overlaid with $1 \mu \mathrm{L}$ HCCA (4-hydroxy- $\alpha$-cinnamic acid) matrix (Bruker Daltonics, Bremen, Germany). Samples were measured automatically by the MALDI Biotyper 3.0; spectra were compared to the Biotyper database and were analysed by flexAnalysis software version 3.3. According to the ranges of score values recommended by the manufacturer (Bruker Daltonics), results were divided into four categories (2.300-3.000: highly probable species identification; 2.000-2.299: secure genus identification, probable species identification; $1.700-1.999$ : probable genus identification; 0.000-1.699: not reliable identification). If score value was lower than 2.000, or MALDI-TOF MS method failed (no peaks found), partial 16S rRNA sequencing was used for the species-level identification of isolates.

For 16S rRNA gene sequencing, overnight liquid cultures of the isolated strains were extracted and purified using the MOBIO Ultra Clean Microbial DNA Isolation Kit (MOBIO Laboratories, USA) following the instructions of the manufacturer. For amplification of $16 \mathrm{~S}$ rRNA genes, bacteria-specific universal primers (27 forward and 1492 reverse) were used (Lane 1991). Reaction parameters were as follows: $98{ }^{\circ} \mathrm{C}$ for $5 \mathrm{~s} ; 32$ cycles of $94{ }^{\circ} \mathrm{C}$ for $30 \mathrm{~s}, 52^{\circ} \mathrm{C}$ for $30 \mathrm{~s}$, and $72{ }^{\circ} \mathrm{C}$ for $45 \mathrm{~s}$; and final extension at $72{ }^{\circ} \mathrm{C}$ for $10 \mathrm{~min}$. The nucleotide sequence determination was performed with the Big Dye Terminator version 3.1. Cycle Sequencing Kit (Applied Biosystems, USA) and sequences were analysed with ABI 3130 Genetic Analyzer (Applied Biosystems, USA). Prior to capillary gel electrophoresis, products were purified by ethanol precipitation. The obtained ( $>400 \mathrm{bp}$ ) sequences were edited and assembled using MEGA5 software ${ }^{\circledR}$ and were searched for homology in the EzBioCloud database (Yoon et al. 2017). Sequence homology over $98 \%$ was accepted as species-level identification. Sequence data obtained in this study were deposited in the National Center for Biotechnology Information (NCBI) GenBank database under the following accession numbers: MT225805-MT225940.

\section{Results}

\section{Background parameters}

At the time of sampling, water samples were dominated by hydrogen-carbonate (over $250 \mathrm{mg} / \mathrm{L}$ ), while sediment samples had a higher concentration of sulphate $(400-800 \mathrm{mg} /$ $\mathrm{kg}$ dry mass) and calcium ions (340-511 mg/kg dry mass). Waterbody showed low bacterial abundance $\left(6 \times 10^{3} \mathrm{cfu} /\right.$ $\mathrm{mL}$ for inflow and $8 \times 10^{2} \mathrm{cfu} / \mathrm{mL}$ for waterbody); faecal indicator Escherichia coli and the opportunistic pathogen Pseudomonas aeruginosa were not detectable. During processing, all abiotic surfaces that come into contact with the carp flesh were sampled and examined for the enumeration of microorganisms. The determined cfu values of cultivable microorganisms were as follows: $4 \times 10^{1} \mathrm{cfu}$ (scaling table), $4.1 \times 10^{4} \mathrm{cfu}$ (deskinning table), $1.2 \times 10^{4} \mathrm{cfu}$ (filleting table), $1.8 \times 10^{3} \mathrm{cfu}$ (packaging table), $4.1 \times 10^{2} \mathrm{cfu}$ (scale), and $<10 \mathrm{cfu}$ (package). Indicator and pathogen microorganisms were not detectable in the processing facility.

\section{Characterization of the microbial community and cell counts}

Microbial communities of the initial and the stored carp samples $\left(96 \mathrm{~h}\right.$ : AP $2{ }^{\circ} \mathrm{C}$, AP $6{ }^{\circ} \mathrm{C}$, VP $2{ }^{\circ} \mathrm{C}$, VP $6{ }^{\circ} \mathrm{C} ; 120$ days: FAP, FAV) were comprehensively characterized by both cultivation-independent (NGS) and cultivation-dependent (MALDI-TOF MS and 16S rRNA sequencing) methods. The OTU cluster analysis, based on the Bray-Curtis similarity index, revealed that the seven examined sample types clustered into three different groups (Fig. 2). The 96-h AP $2{ }^{\circ} \mathrm{C}$ and AP $6{ }^{\circ} \mathrm{C}$ samples and the initial $(0 \mathrm{~h})$, frozen-thawed (120 days) samples formed two distinct clusters, while $96 \mathrm{~h}$ VP $2{ }^{\circ} \mathrm{C}$ and VP $6{ }^{\circ} \mathrm{C}$ samples had more unique community profiles. Based on Shannon indexes, the initial diversity (2.86) decreased during the $2{ }^{\circ} \mathrm{C}$ and $6{ }^{\circ} \mathrm{C}$ storage, and it was the lowest in the case of chilled AP samples $\left(1.76\right.$ at $6{ }^{\circ} \mathrm{C}$ and 2.24 at $2{ }^{\circ} \mathrm{C}$ ), while the highest level of diversity was observed in the frozen-thawed (FAP, FVP) samples (2.94-3.1).

Based on the applied cultivation-dependent methods, initial cell counts of the stored fish samples ranged from $2.5 \times 10^{5}$ to $2.1 \times 10^{6} \mathrm{cfu} / \mathrm{g}$ and showed a steady growth till the end of chilled storage ( $96 \mathrm{~h}$ ) on TGY agar. According to the number of cultivable microorganisms on the TGY medium, the vacuum package at $2{ }^{\circ} \mathrm{C}$ showed the lowest bacterial cell counts, while the aerated package at $6^{\circ} \mathrm{C}$ had the highest cfu values. Based on Pearson's correlation $(r)$ calculated with a confidence interval of $95 \%$, Shannon indexes and colony forming units on TGY agar showed a significant, inverse correlation $(r=-0.8399)$, namely the higher cfu values were associated with lower microbial diversity in the examined samples (Fig. 3). 
Fig. 2 UPGMA dendrogram showing OTU cluster analysis of $16 \mathrm{~S}$ amplicon sequencing data based on the Bray-Curtis similarity index. Initial initial fish fillet sample at $0 \mathrm{~h}$ of the storage experiment; AP $2{ }^{\circ} \mathrm{C}$ - aerobic package stored $96 \mathrm{~h}$ at $2{ }^{\circ} \mathrm{C}$; AP $6{ }^{\circ} \mathrm{C}$ - aerobic package stored $96 \mathrm{~h}$ at $6^{\circ} \mathrm{C}$; VP $2{ }^{\circ} \mathrm{C}$ - vacuum package stored $96 \mathrm{~h}$ at $2{ }^{\circ} \mathrm{C}$; VP $6{ }^{\circ} \mathrm{C}$ — vacuum package stored $96 \mathrm{~h}$ at $6{ }^{\circ} \mathrm{C} ; \mathrm{FAP}$ - frozen-thawed aerobic package stored 120 days at $-18^{\circ} \mathrm{C}$; FVP - frozenthawed vacuum package stored 120 days at $-18^{\circ} \mathrm{C}$

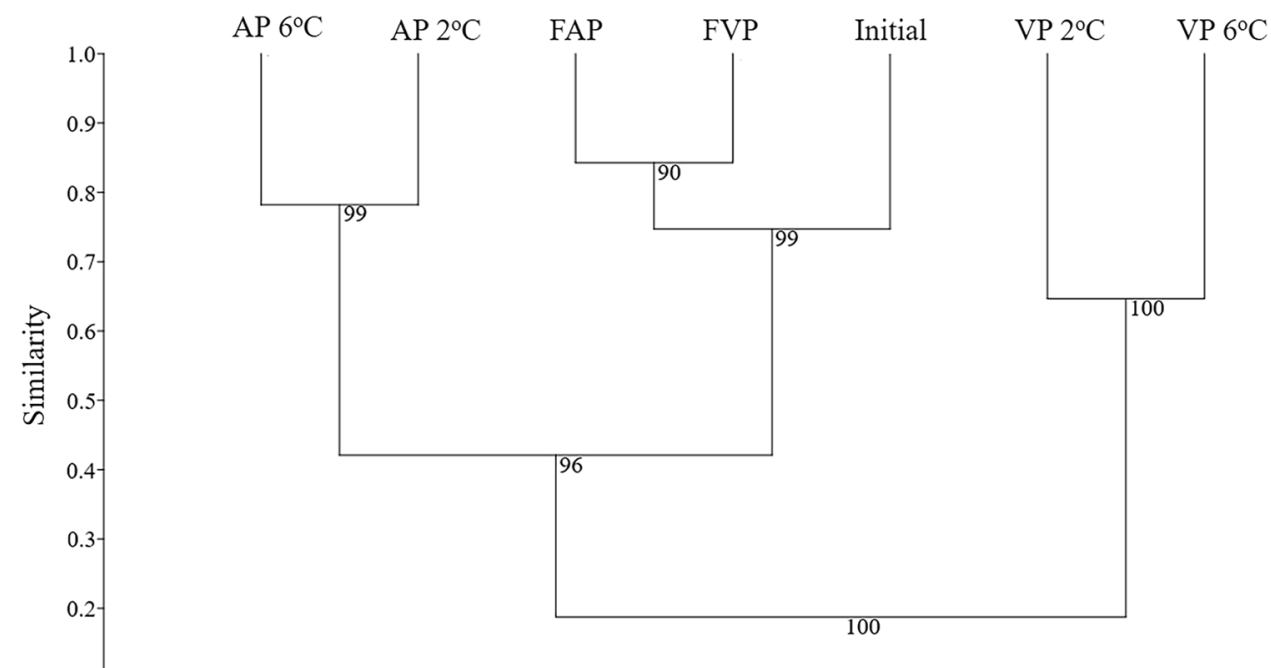

The distribution and the relative abundance of the microbial community revealed by cultivation-independent (NGS) and cultivation-dependent (MALDI-TOF MS, partial 16S rRNA sequencing) methods are summarized in Fig. 4. The applied NGS method proved that members of Proteobacteria (45.5-91\%), Firmicutes (3.5-42\%), Bacteroidetes (0.6-21.7\%), and Actinobacteria (0.3-29.3\%) dominated all microbial communities (Fig. 4A). The relative abundance of Proteobacteria species was influenced by the package type: the initial ratio $(69 \%)$ increased in the AP $2{ }^{\circ} \mathrm{C}$ and $6{ }^{\circ} \mathrm{C}$ samples to $83-91 \%$ during storage, while it decreased in both VP (52-57\%) and frozenthawed (45-47\%) samples. The abundance of Firmicutes

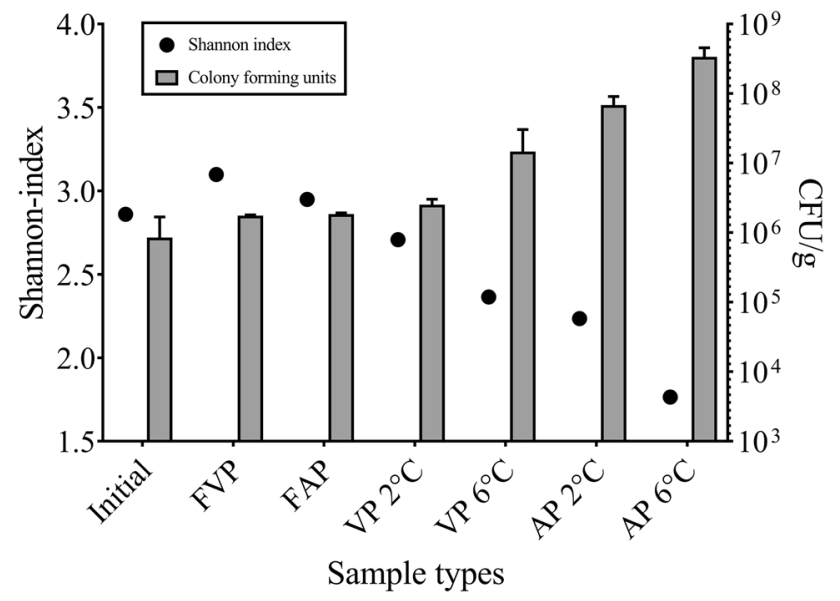

Fig. 3 Microbial diversity (Shannon index) of the carp samples indicated by $16 \mathrm{~S}$ Illumina amplicon sequencing and the average values of colony forming units (cfu) on TGY medium. Initial — initial fish fillet sample at $0 \mathrm{~h}$ of the storage experiment; AP $2{ }^{\circ} \mathrm{C}-$ aerobic package stored $96 \mathrm{~h}$ at $2{ }^{\circ} \mathrm{C}$; AP $6{ }^{\circ} \mathrm{C}$ - aerobic package stored $96 \mathrm{~h}$ at $6{ }^{\circ} \mathrm{C}$; VP $2{ }^{\circ} \mathrm{C}$ - vacuum package stored $96 \mathrm{~h}$ at $2{ }^{\circ} \mathrm{C}$; VP $6{ }^{\circ} \mathrm{C}-$ vacuum package stored $96 \mathrm{~h}$ at $6^{\circ} \mathrm{C}$; FAP — frozen-thawed aerobic package stored 120 days at $-18{ }^{\circ} \mathrm{C}$; FVP - frozen-thawed vacuum package stored 120 days at $-18^{\circ} \mathrm{C}$ phylum was low in the initial and frozen-thawed samples (3.2-5.4\%), slightly increased in the AP samples (7.9-11.6\%) and became substantial in the VP samples (42-39.6\%). At lower temperatures, a slightly higher Firmicute ratio was observed in both VP and AP samples. Bacteroidetes were abundant in the initial (15.5\%) and frozen-thawed samples (19.7-21.7\%) but not in the chilled AP and VP samples (0.6-2.5\%). The Actinobacteria phylum showed the same distribution as the Bacteroidetes: the most abundant genera (Rhodococcus, Galactobacter, and Arthrobacter) had a relatively high abundance in the initial and frozen-thawed samples but decreased in AP and VP samples.

Based on cultivation-dependent identification results, Bacteroidetes and Proteobacteria phyla were isolable from all samples, while Actinobacteria and Firmicutes members were only marginally detectable (see Fig. 4B).

\section{Species-level identification of the microbial community}

The 16S rRNA gene sequences obtained from NGS data and the partial $16 \mathrm{~S}$ rRNA sequences of the cultivated isolates had at least $400 \mathrm{bp}$ length and showed a $98.2-100 \%$ similarity with the reference sequences of the EzBioCloud database (Yoon et al. 2017). According to Franzén et al. (2015), the applied sequence lengths and similarity levels enabled a species-level prediction to reveal the dominant species of carp fillet samples. The species-level identification of the most abundant 20 OTUs obtained by NGS and their cultivable counterparts is summarized in Table 1.

Within Bacteroidetes, the dominance of the Chryseobacterium species was observable. Based on our NGS dataset, three species ( $C$. ginsengiterrae, $C$. piscium, and $C$. shigense) were abundant in the initial and frozen-thawed 


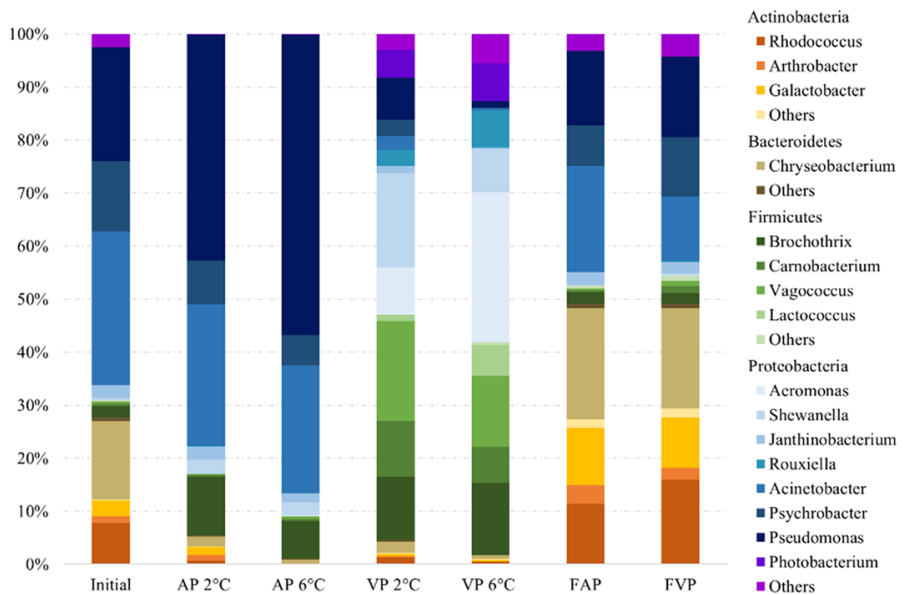

(A)

Fig. 4 Distribution of the microbial community of common carp samples obtained by Illumina 16S rRNA gene amplicon sequencing (A) and cultivation-dependent methods (B). Initial - initial fish fillet sample at $0 \mathrm{~h}$ of the storage experiment; AP $2{ }^{\circ} \mathrm{C}$ - aerobic package stored $96 \mathrm{~h}$ at $2{ }^{\circ} \mathrm{C}$; AP $6{ }^{\circ} \mathrm{C}$ - aerobic package stored $96 \mathrm{~h}$ at $6{ }^{\circ} \mathrm{C}$;

samples (2.0-7.5\%). Among Actinobacteria, Rhodococcus erythropolis and Galactobacter caseinivorans were the most abundant species; both were detectable in the initial (3\%)

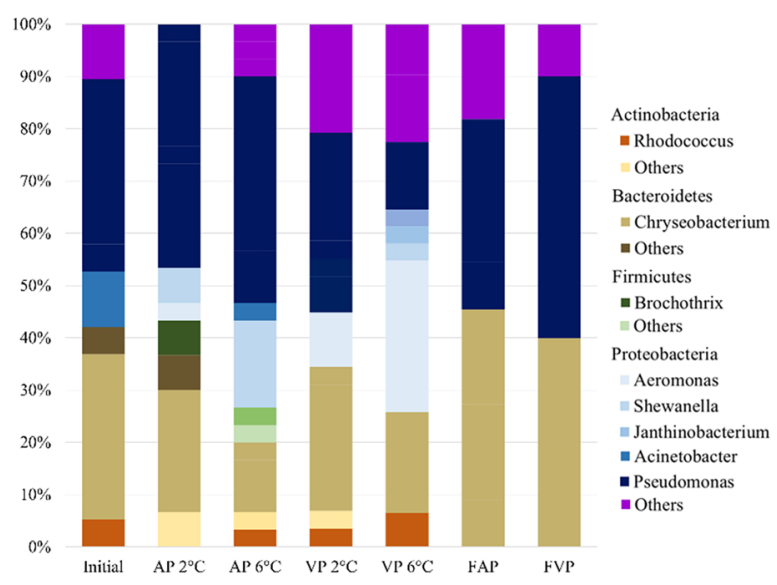

(B)

VP $2{ }^{\circ} \mathrm{C}$ - vacuum package stored $96 \mathrm{~h}$ at $2{ }^{\circ} \mathrm{C}$; VP $6{ }^{\circ} \mathrm{C}$ - vacuum package stored $96 \mathrm{~h}$ at $6{ }^{\circ} \mathrm{C}$; FAP — frozen-thawed aerobic package stored 120 days at $-18{ }^{\circ} \mathrm{C}$; FVP - frozen-thawed vacuum package stored 120 days at $-18^{\circ} \mathrm{C}$

and the frozen-thawed flesh samples (2.9-15.2\%). Bacteroidetes and Actinobacteria species significantly decreased during all types of chilled storage. Among Firmicutes,

Table 1 The most abundant OTUs of common carp fillets and their cultivable counterparts

\begin{tabular}{|c|c|c|c|c|c|c|c|c|c|c|c|}
\hline \multirow{3}{*}{ Genus } & \multirow{3}{*}{$\begin{array}{l}\text { Cultivation-independent (NGS) } \\
\text { identification }\end{array}$} & \multirow{3}{*}{$\begin{array}{c}\text { 16S rRNA } \\
\text { gene } \\
\text { homology } \\
(\%)\end{array}$} & \multicolumn{7}{|c|}{ Rate of OTUs in microbial community (\%) } & \multirow{3}{*}{$\begin{array}{l}\text { Cultivation-dependent } \\
\text { identification }\end{array}$} & \multirow{3}{*}{$\begin{array}{c}\text { 16S rRNA } \\
\text { gene } \\
\text { homology } \\
(\%)\end{array}$} \\
\hline & & & \multirow[b]{2}{*}{ Initial } & \multicolumn{2}{|c|}{$120 \mathrm{~d}$} & \multicolumn{4}{|c|}{$96 \mathrm{~h}$} & & \\
\hline & & & & FAP & FVP & $\begin{array}{c}\mathrm{AP} \\
2{ }^{\circ} \mathrm{C} \\
\end{array}$ & $\begin{array}{c}\mathrm{AP} \\
6{ }^{\circ} \mathrm{C} \\
\end{array}$ & $\begin{array}{c}\mathrm{VP} \\
2{ }^{\circ} \mathrm{C} \\
\end{array}$ & $\begin{array}{c}\mathrm{VP} \\
6{ }^{\circ} \mathrm{C} \\
\end{array}$ & & \\
\hline & Chryseobacterium shigense & 99.35 & 2.05 & 3.63 & 2.69 & 0.22 & 0.04 & 0.15 & 0.10 & not isolated & - \\
\hline Bacteroidetes & s Chryseobacterium ginsengiterrae* & 99.35 & 4.51 & 7.50 & 6.83 & 0.75 & 0.19 & 0.46 & 0.27 & Chryseobacterium ginsengiterrae & 100.00 \\
\hline & Chryseobacterium piscium & 99.35 & 6.23 & 7.11 & 6.17 & 0.80 & 0.38 & 0.74 & 0.18 & Chryseobacterium piscium & 100.00 \\
\hline \multirow{2}{*}{ Actinobacteria } & Rhodococcus erythropolis* & 99.33 & 7.75 & 11.32 & 15.20 & 0.67 & 0.06 & 1.32 & 0.52 & Rhodococcus erythropolis & 100.00 \\
\hline & ${ }^{a}$ Galactobacter caseinivorans* & 99.55 & 2.97 & 10.85 & 9.46 & 1.52 & 0.02 & 0.55 & 0.25 & not isolated & - \\
\hline \multirow{3}{*}{ Firmicutes } & Brochothrix thermosphacta & 99.35 & 2.04 & 2.25 & 2.03 & 11.10 & 7.02 & 11.78 & 13.54 & Brochothrix thermosphacta & 100.00 \\
\hline & Carnobacterium maltaromaticum & 99.57 & 0.54 & 0.41 & 1.31 & 0.27 & 0.33 & 10.37 & 6.57 & not isolated & - \\
\hline & Vagococcus vulneris* & 99.14 & 0.39 & 0.22 & 0.93 & 0.20 & 0.53 & 18.70 & 13.24 & not isolated & - \\
\hline \multirow{13}{*}{ Proteobacteri } & Aeromonas sobria species complex & 99.35 & 0.06 & 0.02 & 0.05 & 0.03 & 0.20 & 8.77 & 27.91 & Aeromonas sobria & 100.00 \\
\hline & Shewanella baltica & 98.28 & 0.29 & 0.03 & 0.26 & 2.47 & 2.25 & 15.33 & 7.54 & Shewanella baltica & 99.75 \\
\hline & Janthinobacterium lividum & 99.78 & 2.44 & 2.43 & 2.22 & 2.44 & 1.64 & 1.42 & 0.16 & Janthinobacterium lividum & 100.00 \\
\hline & Rouxiella chamberiensis* & 99.57 & 0.05 & 0.06 & 0.18 & 0.21 & 0.15 & 3.00 & 6.85 & not isolated & - \\
\hline & Acinetobacter celticus $*$ & $97.85 * *$ & 4.89 & 5.10 & 3.29 & 3.12 & 3.21 & 0.44 & 0.11 & Acinetobacter celticus & $97.39 * *$ \\
\hline & Acinetobacter harbinensis & 99.36 & 7.93 & 1.18 & 1.69 & 14.14 & 15.12 & 0.61 & 0.05 & not isolated & - \\
\hline & Acinetobacter albensis* & 99.36 & 14.33 & 12.36 & 6.34 & 8.44 & 3.98 & 1.41 & 0.29 & Acinetobacter albensis & 99.84 \\
\hline & Psychrobacter cibarius & 100.00 & 7.93 & 3.59 & 4.96 & 7.10 & 5.47 & 2.33 & 0.09 & not isolated & - \\
\hline & Psychrobacter phenylpyruvicus & 99.35 & 5.36 & 4.12 & 6.21 & 1.15 & 0.32 & 0.62 & 0.04 & not isolated & - \\
\hline & Pseudomonas psychrophile & 99.78 & 12.73 & 5.19 & 6.65 & 32.65 & 51.78 & 5.48 & 0.76 & Pseudomonas psychrophila & 99.34 \\
\hline & Pseudomonas azotoformans* & 99.35 & 8.67 & 8.71 & 8.28 & 10.03 & 5.00 & 2.42 & 0.43 & Pseudomonas azotoformans & 100.00 \\
\hline & Photobacterium carnosum & 99.78 & 0.06 & 0.00 & 0.02 & 0.01 & 0.00 & 5.24 & 6.99 & not isolated & - \\
\hline & Others & - & 8.78 & 13.93 & 15.24 & 2.68 & 2.30 & 8.84 & 14.12 & & - \\
\hline
\end{tabular}

Blue colour - relative abundance (dark — high-abundance OTUs); initial - initial fish fillet sample at $0 \mathrm{~h}$ of the storage experiment; AP $2{ }^{\circ} \mathrm{C}$ - aerobic package stored $96 \mathrm{~h}$ at $2{ }^{\circ} \mathrm{C}$; AP $6{ }^{\circ} \mathrm{C}$ - aerobic package stored $96 \mathrm{~h}$ at $6{ }^{\circ} \mathrm{C} ; \mathrm{VP} 2{ }^{\circ} \mathrm{C}$ - vacuum package stored $96 \mathrm{~h}$ at $2{ }^{\circ} \mathrm{C}$; VP $6{ }^{\circ} \mathrm{C}$ - vacuum package stored $96 \mathrm{~h}$ at $6{ }^{\circ} \mathrm{C}$; FAP — frozen-thawed aerobic package stored 120 days at $-18{ }^{\circ} \mathrm{C} ; \mathrm{FVP}$ - frozen-thawed vacuum package stored 120 days at $-18^{\circ} \mathrm{C}$

*Previously unknown contributors in carp storage

**Low homology with type strain 
Brochothrix thermosphacta, a common fish spoilage organism (Stanborough et al. 2017), was detectable in the initial and frozen-thawed samples and became one of the most abundant species in AP and VP samples (11.2-13.5\%). Similarly, Carnobacterium maltaromaticum (formerly $C$. piscicola) dominated the microbial communities of VP samples (6.6-10.4\%). Another Firmicutes, Vagococcus vulneris, a Gram-positive, catalase-negative, coccus-shaped, motile, lactic bacterium, which was recently described as a new species isolated from a human foot wound (Shewmaker et al. 2019), showed abundance (13.2-18.7\%) in VP samples.

Proteobacteria species were highly abundant in all examined sample types. Pseudomonads, such as P. psychrophila and $P$. azotoformans, were found in large numbers. The initial abundance $(12.7 \%)$ of $P$. psychrophila increased in the AP samples (32.7-51.8\%), while it was less significant in the VP and frozen-thawed samples (6.7-0.8\%). P. azotoformans, showed a similar distribution, but elevated temperature $\left(6^{\circ} \mathrm{C}\right)$ had a negative effect on its growth. Among Acinetobacters, our study revealed that the most abundant OTU in the initial sample (14.3\%) has a $99.36 \%$ similarity to $A$. albensis. The initial ratio of this genotype decreased in both AP and VP samples during storage. The second most abundant species from the Acinetobacter genus was A. harbinensis, a species recently described from a river in China ( $\mathrm{Li}$ et al. 2014). According to our results, the initial abundance (7.9\%) of A. harbinensis almost doubled in both AP samples (14.1-15.1\%), but vacuum package and freezing were not favourable for the growth of this bacterium. Another frequent $(4.8 \%)$ genotype of the initial sample showed a $97.9 \%$ homology with the psychrotolerant species A. celticus, previously isolated from natural soil and water samples (Krizova et al. 2016); however, the determined sequence homology with the A. celticus type strain was low. Among aeromonads, Aeromonas sobria species complex was detected by NGS in VP samples (8.8-27.9\%). Among Psychrobacters, $P$. cibarius and $P$. phenylpyruvicus were represented in the initial samples (5.3-7.9\%). P. cibarius remained abundant in AP samples (5.4-7.1\%), while the ratio of P. phenylpyruvicus decreased (0.32-1.15\%). Shewanella baltica, a known opportunistic microbial pathogen of humans and aquatic animals, which is often linked to the spoilage of chilled food products (Beaz-Hidalgo et al. 2014), was not abundant in the initial sample $(0.3 \%)$ but slightly increased in the AP samples (2.3-2.5\%) and became important in the VP $2{ }^{\circ} \mathrm{C}$ (7.5\%) and especially in the VP $6{ }^{\circ} \mathrm{C}$ sample (15\%). Among Photobacterium species, $P$. carnosum was identified in the VP samples (5.2-6.9\%), but not in the AP samples. Janthinobacterium lividum was detectable in the initial and AP samples stored at $2{ }^{\circ} \mathrm{C}(2.4 \%)$, and frozen-thawed storage did not affect its abundance. At the same time, it was less abundant in samples stored at $6{ }^{\circ} \mathrm{C}$ or in VP (1.6-0.2\%).
In VP samples, a facultative anaerobe representative of a new genus within Proteobacteria, Rouxiella chamberiensis, became an abundant species (3.0-6.8\%) which was firstly isolated and described from parental nutrition bags (Le Flèche-Matéos et al. 2015).

Parallelly with NGS, 220 strains were isolated with cultivation-dependent methods, of which 161 cultures were successfully identified at the species level, based on partial 16S rRNA gene sequence homology and/or MALDI-TOF MS. The identified isolates belonged to 52 different species. Dominant species were the members of Pseudomonas synxantha/mucidolens/azotoformans/libanensis/lactis/paralactis group (21.1\%), Chryseobacterium ginsengiterrae (13.6\%), Pantoea agglomerans (6.1\%), and Chryseobacterium piscium $(5.5 \%)$. The complete list of the isolated and identified isolates and the detailed results of cultivation and identification processes are summarized in Supplementary materials (S1-S3). Despite the application of special cultivation media, nine of the most abundant 20 species were not cultivable. At the same time, several Aeromonas species were cultivable from vacuum packed fillets, such as A. veronii/ichtiosmia, A. media/rivipollensis, A. salmonicida/bestiarum/popoffii, and A. encheleia, but similarly to NGS results, the discriminatory power of partial $16 \mathrm{~S}$ rRNA sequencing did not enable a reliable species-level identification of Aeromonads.

\section{Discussion}

The microbial composition of freshwater fish products is still in great interest to increase the shelf-life of raw products. Hungary is the 3rd largest producer of common carp (Cyprinus carpio) in Europe (FAO 2021) and a good representative of the regional climatic and production conditions. Our aim was to evaluate the initial microbiological state of carp fillets and their changes under different storage and package conditions and to identify new members of stored carp fillets with the parallel application of NGS and cultivation-dependent methods. Comparing to scientific literature, the determined cfu values of the initial carp fillets were unexpectedly high, only slightly below the initial contamination level for raw fish immediately after production (Stannard 1997) but did not reach the maximum microbial load limit of freshwater fish (Odeyemi et al. 2020). The possible sources of this initial microbial load of the flesh are the skin, gills, intestine, fish processing technology, or environmental contamination (Sterniša et al. 2016). Since the examined aquaculture and the abiotic surfaces during processing showed low cfu values, the high initial cell counts of fillets can be attributed to a cross-contamination originating from the skin, gills, or intestine occurring during temporary storage or processing. Microbial rejection point, determined as $10^{7} \mathrm{cfu} / \mathrm{g}$ (ICMSF 
1986), was reached after $96 \mathrm{~h}$ in $\mathrm{AP} 2{ }^{\circ} \mathrm{C}$, AP $6{ }^{\circ} \mathrm{C}$, and VP $2{ }^{\circ} \mathrm{C}$ samples, but microbial levels stayed lower than the usual cell counts at the moment of sensory rejection determined as $10^{9} \mathrm{cfu} / \mathrm{g}$ (Kuuliala et al. 2018). During storage, the increasing bacterial numbers paired with a loss of diversity due to a subset of bacteria that became dominant are in accordance with a recent study on refrigerated pork (Li et al. 2019). Based on cluster analysis, the effect of temperature and package type on the microbial community of carp fillets was supplemented with new information. In a recent study, Pan et al. (2018) verified that the microbial communities of stored crips grass carp fillets do not cluster based on packaging. Our results support that in the initial phase of common carp storage, the package type is a determining factor in clustering, while temperature affects the bacterial cell counts.

The revealed composition of microbial communities with the dominance of Proteobacteria, Firmicutes, Bacteroidetes, and Actinobacteria is in accordance with previous investigations (Wang et al. 2017; Li et al. 2018) using 16S rRNA gene identification of bacterial isolates obtained from chilled carp fillets, but Firmicutes did not reach the overwhelming dominance reported previously after 12-day-long storage (Zhang et al. 2015). The microbial composition of the examined carp samples revealed previously unknown members of raw flesh microbiota. Eight out of the top twenty species identified by NGS have never been linked to raw carp fillet samples, and their direct or indirect effects on spoilage are unknown.

Among Bacteroidetes, little is known about the identified Chryseobacterium species ( $C$. ginsengiterrae, $C$. piscium, and $C$. shigense) found in the initial and frozenthawed samples. The type strain (LMG 23,089) of C. piscium was previously isolated from fresh fish caught in the South Atlantic Ocean (de Beer et al. 2006). C. shigense was detected from a beverage in Japan (Shimomura et al. 2005) and was isolated from farmed rainbow trout during disease outbreaks (Zamora et al. 2012). C. ginsengiterrae was recently isolated from a ginseng field (Noh et al. 2017) and has not been previously identified in raw food products. Based on scientific sources, psychrotolerant Chryseobacterium species can cause spoilage defects due to their proteolytic and lipolytic activity as it was described in raw milk samples (Yuan et al. 2018) but, considering their low numbers in $96 \mathrm{~h} \mathrm{AP}$ and VP samples, the effect of the identified species on the quality of stored carp seems to be negligible.

Similarly, the role of the identified Actinobacteria, $R$. erythropolis, and G. caseinivorans, in chilled storage or food spoilage, has not been specified previously in scientific literature. G. caseinivorans needs further attention since it was recently described from bulk tank raw cow's milk from three different dairy farms in Germany (Hahne et al. 2019b), which underlines its importance in raw animal food products.
Among Firmicutes, the potential contributor to carp spoilage under the examined package and temperature conditions was Brochothrix thermosphacta, a fermentative bacterium. B. thermosphacta can be dominant in vacuum-packed food products (Nowak et al. 2012), produces organoleptically unpleasant compounds, and its role in shortening the shelflife of food makes it significant in aerobic storage as well. C. maltaromaticum, a commonly detectable species in cold environments and chilled food, such as meat, seafood, and dairy products (Leisner et al. 2007), was another abundant species in vacuum packages, which is in accordance with previous reports of modified-atmosphere-packed food (PaludanMüller et al. 1998; Paarup et al. 2002). However, the volatile molecules produced by this species have low sensory impacts (Casaburi et al. 2011). There is no available information of the newly detected storage organism Vagococcus vulneris, but the closely related $V$. salmoninarum is a verified producer of 2-heptanone, 2-nonanone, and 2-undecanone (Calliauw et al. 2016). In the future, V. vulneris should be cultivated, identified with complete $16 \mathrm{~S}$ rRNA sequencing, and its spoilage potential should be examined to clarify its effects on sensory characteristics.

Among Proteobacteria, Pseudomonas, Acinetobacter, and Psychrobacter genera were the most abundant in the initial raw fillets following the previous findings on stored silver carp (Jia et al. 2018). Regarding Pseudomonads, there is a debate in the scientific literature on P. lindens, P. fluorescens, P. putida, and $P$. fragi/psychrophila, as the dominant members of the microbial community in chilled meat and fish (Wickramasinghe et al. 2019; Gennari and Dragotto 1992). Our results emphasize the importance of $P$. psychrophila, a species that can form a substantial amount of biofilm during chilled storage, providing favourable conditions for the growth and persistence of pathogenic E. coli (Sterniša et al. 2019). Based on our results, the overwhelming dominance of $P$. psychrophila is verified in AP samples, while its abundance in VP and frozen-thawed samples was lower following the findings of Tryfinopoulou et al. (2002).

Acinetobacter spp. are typical members of the psychrophilic spoilage microbiota of chilled foods (Betts 2006; Li et al. 2017b) and were represented in our dataset, too. A. harbinensis was previously detected in silver carp fillets stored at $4{ }^{\circ} \mathrm{C}$ (Jia et al. 2018), but $A$. albensis, a species recently isolated and described from a well-protected landscape area in the Czech Republic (Krizova et al. 2015), was just proved to be predominant in raw milk samples (Hahne et al. 2019a) and had no link to fish products. While these uncommon species were detectable, $A$. johnsonii, a frequent species in fish and fish products (Zhang et al. 2015), or A. lwoffii, a predominant species of spoiled food (Kampfer 2000), were not abundant in our NGS dataset, and only one A. johnsonii strain was cultivable. According to metagenomic studies, the possible source of the detected Acinetobacter species is 
the gut microbiota of carp (Hovda et al. 2007; Etyemez and Balcázar 2015). Regarding Aeromonads, the occurrence of A. sobria species complex was in accordance with data of stored and refrigerated foods such as raw fish (Alhazmi 2015) and vacuum-packed milkfish (Simon et al. 2016). However, considering the low discriminatory power of 16S rRNA for the genera Acinetobacter (Alvarez-Buylla et al. 2012) and Aeromonas (Miñana-Galbis 2009), additional identification methods are recommended in the future to reach a reliable differentiation at the species level. Regarding Psychrobacters, the available information on the identified species supports their minor role in spoilage defects. $P$. cibarius does not produce a significant amount of volatile organic compounds at $4{ }^{\circ} \mathrm{C}$, just a slight amount of trimethylamine (TMA) (Broekaert et al. 2013). Regarding P. phenylpyruvicus, our findings agree with previous reports describing its decrease at the latter stage of cold storage of freshwater fish (González et al. 2000). The identified Shewanella species, S. baltica, may play a significant role in spoilage since it is the most important $\mathrm{H}_{2} \mathrm{~S}$-producing bacterium in ice-stored marine fish (Vogel et al. 2005) with a possible role in modifying texture and sensory characteristics (Serio et al. 2014). The detected Photobacterium species, P. carnosum, was abundant in $96 \mathrm{~h}$ VP samples following previous findings of its adaptability to modified-atmosphere environments (Hilgarth et al. 2018; Fuertez-Perez et al. 2019). Photobacteria produce biogenic amines and other spoilage compounds (Takahashi et al. 2015; Höll et al. 2019), contributing to the spoilage of modified air products. Janthinobacterium is a basic group of marine fish gut microbiota (Egerton et al. 2018) with the ability to produce exopolysaccharide-rich biofilms (Pantanella et al. 2007), but the identified species, J. lividum, has not been reported previously in stored fish fillets. Similarly, the identified Rouxiella species, $R$. chamberiensis, was recently proved to be a member of salmon gut microbiota (Higuera-Llantén et al. 2018), but our result is the first verification of its presence in carp products. According to scientific literature, the possible source of J. lividum and $R$. chamberiensis is the carp gut microbiota and their possible role in spoilage should be characterized in the future.

\section{Conclusions}

This paper aims to improve the understanding and knowledge of the storage microbiota of carp fillet originated from a European polyculture with low population density. High initial cell counts emphasize that under the given climatic and production conditions (e.g. higher water temperatures in aquaculture and during temporary storage, higher initial microbial load of gills, integument, or in the digestion system), microbial rejection point can be reached rapidly if package and storage conditions are not optimal. Our results verified that in the initial phase of chilled storage of common carp, the package type is a determining factor in clustering, while temperature primarily affects the bacterial cell counts. To increase shelf-life, the initial microbial load of raw carp fillets should be decreased with the close monitoring of transport, processing, and storage conditions, whenever possible. The recommended storage of freshwater carp fillets is the vacuum package at $2{ }^{\circ} \mathrm{C}$. Based on our NGS results, the microbial composition of the examined initial and stored common carp samples is slightly different from the previously described microbiotas. Cultivation-dependent identification methods revealed only $45.0 \%$ of the most abundant 20 OTUs identified by NGS. Since the applied species-level identification methods have their limitations, a complete $16 \mathrm{~S}$ rRNA sequence analysis is required in the future to verify the species-level identification of the detected genotypes. Our results suggest that under the local climatic and production conditions, several uncommon, presumably fish gut or environmentally transmitted bacteria are abundant during the initial storage of common carp. The newly detected members of carp fillet microbiota, such as Vagococcus vulneris, Rouxiella chamberiensis, and Acinetobacter albensis, have a still unknown role in spoilage and shelf-life. In the future, knowing the members of the initial microbial community of flesh enables the optimization of processing and storage technology to reach a high level of compliance with food safety requirements that are significant for the development of production and storage.

Supplementary information The online version contains supplementary material available at https://doi.org/10.1007/s12223-021-00935-4.

Author contribution Conceptualization: Edit Kaszab, Brigitta NyírőFekete, Sándor Szoboszlay; methodology: Edit Kaszab, Milán Farkas; investigation: Edit Kaszab, Milán Farkas, Júlia Radó; visualization: Edit Kaszab, Milán Farkas; software: Milán Farkas; data curation: Sándor Szoboszlay, István Szabó; writing — original draft preparation: Edit Kaszab, Milán Farkas, Júlia Radó; writing — review and editing: Edit Kaszab; funding acquisition: Adrienn Micsinai, Balázs Kriszt, Béla Urbányi, Sándor Szoboszlay; project administration: Adrienn Micsinai, Brigitta Nyírő-Fekete, Balázs Kriszt; resources: Adrienn Micsinai, Balázs Kriszt, Béla Urbányi, Sándor Szoboszlay; supervision: István Szabó, Balázs Kriszt, Béla Urbányi, Sándor Szoboszlay.

Funding Open access funding provided by Hungarian University of Agriculture and Life Sciences. This research was supported by the Ministry of Innovation and Technology within the framework of the Thematic Excellence Programme 2020, National Challenges Subprogramme (TKP2020-NKA-16), and by the HappyFish Project (NVKP16-1-2016-0023). The scientific work of Edit Kaszab and István Szabó was supported by the János Bolyai Research Grant of the Hungarian Academy of Sciences.

Data availability Data generated or analysed during this study are included in this published article [and its supplementary information files], or available from the corresponding author on reasonable request. 


\section{Declarations}

Conflict of interest The authors declare no competing interests.

Open Access This article is licensed under a Creative Commons Attribution 4.0 International License, which permits use, sharing, adaptation, distribution and reproduction in any medium or format, as long as you give appropriate credit to the original author(s) and the source, provide a link to the Creative Commons licence, and indicate if changes were made. The images or other third party material in this article are included in the article's Creative Commons licence, unless indicated otherwise in a credit line to the material. If material is not included in the article's Creative Commons licence and your intended use is not permitted by statutory regulation or exceeds the permitted use, you will need to obtain permission directly from the copyright holder. To view a copy of this licence, visit http://creativecommons.org/licenses/by/4.0/.

\section{References}

Alhazmi MI (2015) Isolation of Aeromonas spp. from food products: emerging Aeromonas infections and their significance in public health. J of AOAC Int 98(4):927-929. https://doi.org/10.5740/ jaoacint.14-257

Alvarez-Buylla A, Culebras E, Picazo JJ (2012) Identification of Acinetobacter species: is Bruker biotyper MALDI-TOF mass spectrometry a good alternative to molecular techniques? Infect Genet Evol 12:345-349. https://doi.org/10.1016/j.meegid.2012.01.002

Arashisar S, Hisar O, Yanik M (2004) Effects of modified atmosphere and vacuum packaging on microbiological and chemical properties of rainbow trout (Oncorynchus mykiss) fillets. Int J Food Microbiol 97:209-214. https://doi.org/10.1016/j.ijfoodmicro.2004.05.024

Beaz-Hidalgo R, Agüeria D, Latif-Eugenín F, Yeannes MI, Figueras MJ (2014) Molecular characterization of Shewanella and Aeromonas isolates associated with spoilage of Common carp (Cyprinus carpio). FEMS Microbiol Ecol 362(1):1-8. https://doi.org/ 10.1093/femsle/fnu029

Betts G (2006) Other spoilage bacteria. In C.W. Blackburn (Ed.), Food spoilage microorganisms, Woodhead Publishing Ltd., pp 668-693

Broekaert K, Noseda B, Heyndrickx M, Vlaemynck G, Devlieghere F (2013) Volatile compounds associated with Psychrobacter spp. and Pseudoalteromonas spp., the dominant microbiota of brown shrimp (Crangon crangon) during aerobic storage. Int J Food Microbiol 166(3):487-493. https://doi.org/10.1016/j. ijfoodmicro.2013.08.013

Calliauw F, Horemans B, Broekaert K, Michiels C, Heyndrickx M (2016) Spoilage potential of Vagococcus salmoninarum in preservative-free, MAP-stored brown shrimp and differentiation from Brochothrix thermosphacta on streptomycin thallous acetate actidione agar. J Appl Microbiol 120(5):1302-1312. https://doi. org/10.1111/jam.13107

Casaburi A, Nasi A, Ferrocino I, Di Monaco R, Mauriello G, Villani F, Ercolini D (2011) Spoilage-related activity of Carnobacterium maltaromaticum strains in air-stored and vacuum-packed meat. Appl Environ Microbiol 77(20):7382-7393. https://doi.org/10. 1128/AEM.05304-11

de Beer H, Hugo CJ, Jooste PJ, Vancanneyt M, Coenye T, Vandamme $\mathrm{P}$ (2006) Chryseobacterium piscium sp. nov. isolated from fish of the South Atlantic Ocean off South Africa. Int J Syst Evol Microbiol 56(Pt6):1317-1322. https://doi.org/10.1099/ijs.0.64014-0

Edgar RC, Haas BJ, Clemente JC, Quince C, Knight R (2011) UCHIME improves sensitivity and speed of chimera detection. Bioinformatics 27:2194-2200. https://doi.org/10.1093/ bioinformatics/btr381
Egerton S, Culloty S, Whooley J, Stanton C, Ross RP (2018) The gut microbiota of marine fish. Front Microbiol 9:873. https://doi.org/ 10.3389/fmicb.2018.00873

Etyemez M, Balcázar JL (2015) Bacterial community structure in the intestinal ecosystem of rainbow trout (Oncorhynchus mykiss) as revealed by pyrosequencing-based analysis of $16 \mathrm{~S}$ rRNA genes. Res Vet Sci 100:8-11. https://doi.org/10.1016/j.rvsc.2015.03.026

FAO (2003-2021) National Aquaculture Sector Overview. Hungary. National Aquaculture Sector Overview Fact Sheets. Text by Varadi, L. In: FAO Fisheries Division [online]. Rome. Updated . [Cited 14 July 2021]. https://www.fao.org/fishery/countrysector/ naso_hungary/en\#tcN70027

Franzén O, Hu J, Bao X, Itzkowitz SH, Peter I, Bashir A (2015) Improved OTU-picking using long-read 16S rRNA gene amplicon sequencing and generic hierarchical clustering. Microbiome 3:43. https://doi.org/10.1186/s40168-015-0105-6

Fuertez-Perez S, Hauschild P, Hilgarth M, Vogel RF (2019) Biodiversity of Photobacterium spp. isolated from meats. Front Microbiol 10:2399. https://doi.org/10.3389/fmicb.2019.02399

Gennari M, Dragotto F (1992) A study of the incidence of different fluorescent Pseudomonas species and biovars in the microflora of fresh and spoiled meat and fish, raw milk, cheese, soil and water. J Appl Biol 72(4):281-288. https://doi.org/10.1111/j.1365-2672. 1992.tb01836.x

González CJ, Santos JA, García-López ML, Otero A (2000) Psychrobacters and related bacteria in freshwater fish. J Food Prot 63(3):315-321. https://doi.org/10.4315/0362-028x-63.3.315

Gram L, Huss HH (1996) Microbiological spoilage of fish and fish products. Int J Food Microbiol 33:121-137. https://doi.org/10. 1016/0168-1605(96)01134-8

Hahne J, Isele D, Berning J, Lipski A (2019a) The contribution of fast growing, psychrotrophic microorganisms on biodiversity of refrigerated raw cow's milk with high bacterial counts and their food spoilage potential. Food Microbiol 79:11-19. https://doi.org/ 10.1016/j.fm.2018.10.019

Hahne J, Isele D, Heidler von Heilborn D, Czaja-Hasse L, Hüttel B, Lipski A (2019b) Galactobacter caseinivorans gen. nov, sp. nov. and Galactobacter valiniphilus sp. nov, two novel species of the family Micrococcaceae, isolated from high bacterial count raw cow's milk. Int J Syst Evol Microbiol 69(9):2862-2869. https:// doi.org/10.1099/ijsem.0.003570

Higuera-Llantén S, Vásquez-Ponce F, Barrientos-Espinoza B, Mardones FO, Marshall SH, Olivares-Pacheco J (2018) Extended antibiotic treatment in salmon farms select multiresistant gut bacteria with a high prevalence of antibiotic resistance genes. PLoS ONE 13(9):e0203641. https://doi.org/10.1371/journal. pone. 0203641

Hilgarth M, Fuertes S, Ehrmann M, Vogel RF (2018) Photobacterium carnosum $\mathrm{sp}$. nov, isolated from spoiled modified atmosphere packaged poultry meat. Syst Appl Microbiol 41:44-50. https:// doi.org/10.1016/j.syapm.2017.11.002

Hovda MB, Lunestad BT, Fontanillas R, Rosnes JT (2007) Molecular characterisation of the intestinal microbiota of farmed Atlantic salmon (Salmo salar L.) Aquac 272(1-4):581-588. https://doi. org/10.1016/j.aquaculture.2007.08.045

Höll L, Hilgarth M, Geissler AJ, Behr J, Vogel RF (2019) Prediction of in situ metabolism of photobacteria in modified atmosphere packaged poultry meat using metatranscriptomic data. Microbiol Res 222:52-59. https://doi.org/10.1016/j.micres.2019.03.002

ICMSF (1986) International Commission on Microbiological Specification for Foods: Microorganisms in foods. Sampling for microbiological analysis: principles and specific applications, 2nd Ed. International Commission on Microbiological Specifications for Foods

ISO 6887-2 (2003) Microbiology of food and animal feeding stuffs. Preparation of test samples, initial suspension and decimal 
dilutions for microbiological examination. Part 2: Specific rules for the preparation of meat and meat products

ISO 6887-3 (2017) Microbiology of the food chain - preparation of test samples, initial suspension and decimal dilutions for microbiological examination. Part 3: specific rules for the preparation of fish and fishery products

Ježek F, Buchtová H (2010) Shelf-life of chilled muscle tissue of the common carp (Cyprinus carpio L.) packaged in carbon monoxide enriched modified atmosphere. Acta Vet Brno 79:117-125. https://doi.org/10.2754/avb201079S9S117

Jia SL, Liu XC, Huang Z, Li Y, Zhang LT, Luo YK (2018) Effects of chitosan oligosaccharides on microbiota composition of silver carp (Hypophthalmichthys molitrix) determined by culturedependent and independent methods during chilled storage. Int $\mathbf{J}$ Food Microbiol 268:81-91. https://doi.org/10.1016/j.ijfoodmicro. 2018.01.011

Kampfer P (2000) Acinetobacter. In: Robinson RK, Batt CA, Patel PD (eds) Encyclopaedia of food microbiology. Academic Press, pp 7-15

Klindworth A, Pruesse E, Schweer T, Peplies J, Quast C, Horn M, Glöckner FO (2013) Evaluation of general 16S ribosomal RNA gene PCR primers for classical and next-generation sequencingbased diversity studies. Nucleic Acids Res 41:e1. https://doi.org/ 10.1093/nar/gks808

Kozich JJ, Westcott SL, Baxter NT, Highlander SK, Schloss PD (2013) Development of a dual-index sequencing strategy and curation pipeline for analyzing amplicon sequence data on the MiSeq Illumina sequencing platform. Appl Environ Microbiol 79:51125120. https://doi.org/10.1128/AEM.01043-13

Krizova L, Maixnerova M, Sedo O, Nemec A (2015) Acinetobacter albensis sp. nov, isolated from natural soil and water ecosystems. Int J Syst Evol Microbiol 65:857-863. https://doi.org/10.1099/ ijsem.0.000511

Krizova LR, Maixnerova M, Nemec A (2016) Acinetobacter celticus sp. nov, a psychrotolerant species widespread in natural soil and water ecosystems. Int J Syst Evol Microbiol 66(12):53925398. https://doi.org/10.1099/ijsem.0.001526

Kunin V, Engelbrektson A, Ochman H, Hugenholtz P (2010) Wrinkles in the rare biosphere: pyrosequencing errors can lead to artificial inflation of diversity estimates. Environ Microbiol 12:118-123. https://doi.org/10.1111/j.1462-2920.2009.02051.x

Kuuliala L, Al Hage Y, Ioannidis A-G, Sader M, Kerckhof F-M, Vanderroost M, Boon N, De Baets B, De Meulenaer B, Ragaert P, Devlieghere F (2018) Microbiological, chemical and sensory spoilage analysis of raw Atlantic cod (Gadus morhua) stored under modified atmospheres. Food Microbiol 70:232-244. https://doi.org/10.1016/j.fm.2017.10.011

Lane DJ (1991) 16S/23S rRNA sequencing. In: Stackebrandt E, Goodfellow M (eds) Nucleic Acid Techniques in Bacterial Systematics. John Wiley and Sons, pp 115-175

Le Flèche-Matéos A, Levast M, Lomprez F, Amoux Y, Andorian C, Perraud M, Vincent V, Ar Gouilh M, Thiberge JM, Vanderbogaert M, Diancourt L, Caro V, Burguière AM, Manuguerra JC (2015) Rouxiella chamberiensis gen. nov, sp. nov, a member of the family Enterobacteriaceae isolated from parental nutrition bags. Int J Syst Evol Microbiol 65(Pt6):1812-1818. https://doi.org/10.1099/ ijs.0.000179

Leisner JJ, Laursen BG, Prévost H, Drider D (2007) Carnobacterium: positive and negative effects in the environment and in foods. FEMS Microbiol Rev 31(5):592-613. https://doi.org/10. 1111/j.1574-6976.2007.00080.x

Li W, Zhang D, Huang X, Qin W (2014) Acinetobacter harbinensis sp. nov, isolated from river water. Int J Syst Evol Microbiol 64:1507-1513. https://doi.org/10.1099/ijs.0.055251-0

Li D, Zhang L, Song S, Wang Z, Kong C, Luo Y (2017a) The role of microorganisms in the degradation of adenosine triphosphate
(ATP) in chilled-stored common carp (Cyprinus carpio) fillets. Food Chem 1(224):347-352. https://doi.org/10.1016/j.foodchem. 2016.12.056

Li D, Li Q, Zhang Y, Liu X, Hong H, Luo Y (2017b) Quality changes and microbiological spoilage analysis of air-packed and vacuum-packed silver carp (Hypophthalmichthys molitrix) during chilled storage. J Food Process Preserv 42(4):e13389. https:// doi.org/10.1111/jfpp.13389

Li Q, Zhang L, Luo Y (2018) Changes in microbial communities and quality attributes of white muscle and dark muscle from common carp (Cyprinus carpio) during chilled and freeze-chilled storage. Food Microbiol 73:237-244. https://doi.org/10.1016/j. fm.2018.01.011

Li N, Zhang Y, Wu Q, Gu Q, Chen M, Zhang Y, Sun X, Zhang J (2019) High-throughput sequencing analysis of bacterial community composition and quality characteristics in refrigerated pork during storage. Food Microbiol 83:86-94. https://doi.org/ 10.1016/j.fm.2019.04.013

Miñana-Galbis D, Urbizu-Serrano A, Farfán M, Fusté MC, Lorén JG (2009) Phylogenetic analysis and identification of Aeromonas species based on sequencing of the cpn60 universal target. Int J Syst Evol Microbiol 59:1976-1983. https://doi.org/10.1099/ ijs.0.005413-0

MSZ EN ISO 4833-1 (2014) Microbiology of the food chain. Horizontal method for the enumeration of microorganisms. Part 1: colony count at 30 degrees $\mathrm{C}$ by the pour plate technique (ISO 4833-1:2013)

MSZ EN ISO 6222 (2000) Water quality. Enumeration of culturable micro-organisms. Colony count by inoculation in a nutrient agar culture medium (ISO 6222:1999)

MSZ EN ISO 9963-1 (1998) Water quality. Determination of alkalinity. Part 1: determination of total and composite alkalinity

MSZ EN ISO 10304-1 (2009) Water quality. Determination of dissolved anions by liquid chromatography of ions. Part 1: determination of bromide, chloride, fluoride, nitrate, nitrite, phosphate and sulfate (ISO 10304-1:2007) (ISO 9963-1:1994)

MSZ EN ISO 17294-2 (2005) Water quality. Application of inductively coupled plasma mass spectrometry (ICP-MS) Part 2: Determination of 62 elements (ISO 17294-2:2003)

Noh JH, Hoang VA, Kim YJ, Kang JP, Yang DC (2017) Chryseobacterium ginsengiterrae sp. nov, with $\beta$-glucosidase activity isolated from soil of a ginseng field. Curr Microbiol 74:1417-1424. https://doi.org/10.1007/s00284-017-1335-6

Nowak A, Rygala A, Oltuszak-Walczak E, Walczak P (2012) The prevalence and some metabolic traits of Brochothrix thermosphacta in meat and meat products packaged in different ways. J Sci Food Agric 92(6):1304-1310. https://doi.org/10.1002/jsfa.4701

Odeyemi OA, Alegbeleye OO, Strateva M, Stratev D (2020) Understanding spoilage microbial community and spoilage mechanisms in foods of animal origin. Comp Rev Food Sci Food Safety 19(2):311-331. https://doi.org/10.1111/1541-4337.12526

Paarup T, Sanchez JA, Peláez C, Moral A (2002) Sensory, chemical and bacteriological changes in vacuum-packed pressurised squid mantle (Todaropsis eblanae) stored at $4{ }^{\circ} \mathrm{C}$. Int J Food Microbiol 74:1-12. https://doi.org/10.1016/s0168-1605(01)00701-2

Paludan-Müller C, Dalgaard P, Huss HH, Gram L (1998) Evaluation of the role of Carnobacterium piscicola in spoilage of vacuumand modified-atmosphere-packed cold-smoked salmon stored at $5{ }^{\circ} \mathrm{C}$. Int J Food Microbiol 39:155-166. https://doi.org/10.1016/ S0168-1605(97)00133-5

Pan Z, Li L, Shen Z, Chen Y, Li M (2018) Characterization of the microbiota in air- or vacuum-packed crisp grass carp (Ctenopharyngodon idella $\mathrm{C}$. et $\mathrm{V}$.) fillets by $16 \mathrm{~S}$ rRNA PCR-denaturating gradient gel electrophoresis and high-throughput sequencing. J Food Prot 81(6):1022-1029. https://doi.org/10.4315/0362-028X. JFP-17-498 
Pantanella F, Berlutti F, Passariello C, Sarli S, Morea C, Schippa S (2007) Violacein and biofilm production in Janthinobacterium lividum. J Appl Microbiol 102(4):992-999. https://doi.org/10. 1111/j.1365-2672.2006.03155.x

Parlapani FF, Kormas KA, Boziaris IS (2014) Microbial changes, shelf life and identification of initial and spoilage microbiota of sea bream fillets stored under various conditions using 16S rRNA gene analysis. J Sci Food Agric 95:2386-2394. https://doi.org/ 10.1002/jsfa.6957

Quast C, Pruesse E, Yilmaz P, Gerken J, Schweer T, Yarza P, Peplies J, Glöckner FO (2013) The SILVA ribosomal RNA gene database project: improved data processing and web-based tools. Nucleic Acids Res 41:590-596. https://doi.org/10.1093/nar/gks1219

Schloss PD, Westcott SL, Ryabin T, Hall JR, Hartmann M, Hollister EB, Lesniewski RA, Oakle BB, Parks DH, Robinson CJ, Sahl JW, Stres B, Thallinger GG, Van Horn DJ, Weber CF (2009) Introducing mothur: open-source platform-independent communitysupported software for describing and comparing microbial communities. Appl Environ Microbiol 75:7537-7541. https://doi.org/ 10.1128/AEM.01541-09

Serio A, Fusella GC, López CC, Sachetti G, Paparella A (2014) A survey on bacteria isolated as hydrogen sulfide-producers from marine fish. Food Contol 39:111-118. https://doi.org/10.1016/j. foodcont.2013.11.003

Shewmaker PL, Whitney AM, Gulvik CA, Humrighouse BW, Gartin, J, Barr JR, Moore ERB, Karlsson R, Pinto TCA, Teixeira LM (2019) Vagococcus bubulae sp. nov, isolated from ground beef, and Vagococcus vulneris sp. nov, isolated from a human foot wound. Int J Syst Evol Microbiol 69(8):2268-2276. https:// doi.org/10.1099/ijsem.0.003459

Shimomura K, Kaji S, Hiraishi A (2005) Chryseobacterium shigense sp. nov, a yellow-pigmented, aerobic bacterium isolated from a lactic acid beverage. Int J Syst Evol Microbiol 55(5):1903-1906. https:// doi.org/10.1099/ijs.0.63690-0

Simon SS, Lalitha KV, Joseph T (2016) Virulence properties of Aeromonas spp. from modified-atmosphere- and vacuum-packed milk fish (Chanos chanos Forsskal, 1775) Ann Microbiol 66(3):11091115. https://doi.org/10.1007/s13213-016-1193-7

Stanborough T, Fegan N, Powell SM, Tamplin M, Chandry PS (2017) Insight into the genome of Brochothrix thermosphacta, a problematic meat spoilage bacterium. Appl Environ Microbiol 83(5):e02786-e2816. https://doi.org/10.1128/AEM.02786-16

Stannard C (1997) Development and use of microbiological criteria for foods. Food Sci Technol Today 11(3):137-176

Sterniša M, Mraz J, Možina S (2016) Microbiological aspects of common carp (Cyprinus carpio) and its processing - relevance for final product quality: a review. Aquacul Int 24(6):1569-1590. https://doi.org/10.1007/s10499-016-0051-8

Sterniša M, Klancnik A, Možina S (2019) Spoilage Pseudomonas biofilm with Escherichia coli protection in fish meat at $5{ }^{\circ} \mathrm{C}$. J Sci Food Agric 99(10):4635-4641. https://doi.org/10.1002/jsfa.9703

Takahashi H, Ogai M, Miya S, Kuda T, Kimura B (2015) Effects of environmental factors on histamine production in the psychrophilic histamine producing bacterium Photobacterium iliopiscarium. Food Control 52:39-42. https://doi.org/10.1016/j.foodcont. 2014.12.023
Tindall BJ, Rosselló-Móra R, Busse HJ, Ludwig W, Kämpfer P (2010) Notes on the characterization of prokaryote strains for taxonomic purposes. Int J Syst Evol Microbiol 60:249-266. https://doi.org/ 10.1099/ijs.0.016949-0

Tryfinopoulou P, Trsakalidou E, Nychas G-JE (2002) Characterization of Pseudomonas spp. associated with spoilage of gild-head sea bream stored under various conditions. Appl Environ Microbiol 69(1):65-72. https://doi.org/10.1128/aem.68.1.65-72.2002

Vogel BF, Venkateswaran K, Satomi M, Gram L (2005) Identification of Shewanella baltica as the most important H2S-producing species during iced storage of Danish marine fish. Appl Environ Microbiol 71(11):6689-6697. https://doi.org/10.1128/AEM.71. 11.6689-6697.2005

Wang H, Liu X, Zhang Y, Lu H, Xu Q, Shi C, Luo Y (2017) Spoilage potential of three different bacteria isolated from spoiled grass carp (Ctenopharyngodon idellus) fillets during storage at $4{ }^{\circ} \mathrm{C}$. LWT - Food Sci Technol 81:10-17. https://doi.org/10.1016/j.lwt. 2016.11.010

Wickramasinghe NN, Ravensdale J, Coorey R, Chandry SP, Dykes GA (2019) The predominance of psychrotrophic Pseudomonads on aerobically stored chilled red meat. Compr Rev Food Sci Food Saf 18(5):1622-1635. https://doi.org/10.1111/1541-4337.12483

Yoon SH, Ha SM, Kwon S, Lim J, Kim Y, Seo H, Chun J (2017) Introducing EzBioCloud: a taxonomically united database of $16 \mathrm{~S}$ rRNA and whole genome assemblies. Int J Syst Evol Microbiol 67:1613-1617. https://doi.org/10.1099/ijsem.0.001755

Yuan L, Sadiq FA, Liu T-j, Li Y, Gu J-s, Yang H-y, He G-q (2018) Spoilage potential of psychrotrophic bacteria isolated from raw milk and the thermo-stability of their enzymes. J Zhejiang Univ Sci B 19(8):630-642. https://doi.org/10.1631/jzus.B1700352

Zamora L, Vela AI, Palacios MA, Domínguez L, FernándezGarayzábal JF (2012) First isolation and characterization of Chryseobacterium shigense from rainbow trout. BMC Vet Res 8:77. https://doi.org/10.1186/1746-6148-8-77

Zhang Y, Li Q, Li D, Liu X, Luo Y (2015) Changes in the microbial communities of air-packaged and vacuum-packaged common carp (Cyprinus carpio) stored at $4{ }^{\circ} \mathrm{C}$. Food Microbiol 52:197-204. https://doi.org/10.1016/j.fm.2015.08.003

Zhang Y, Li D, Lv J, Li Q, Kong C, Luo Y (2017a) Effect of cinnamon essential oil on bacterial diversity and shelf-life in vacuumpackaged common carp (Cyprinus carpio) during refrigerated storage. Int J Food Microbiol 249(16):1-8. https://doi.org/10. 1016/j.ijfoodmicro.2016.10.008

Zhang J, Song S, Li D, Luo Y (2017b) Microbial communities and biogenic amines of crucian carp (Carassius auratus) fillets during partial freezing and chilled storage. Int J Food Prop (sup1):S1053-S1064 https://doi.org/10.1080/10942912.2017.1326938

\section{Web references}

https://www.mothur.org/wiki/MiSeq_SOP Date of last accession: 13. 03. 2020

Publisher's Note Springer Nature remains neutral with regard to jurisdictional claims in published maps and institutional affiliations. 